acquainted firsthand with its history and contemporary achievements. The final stint would be in Africa, devoted to a variety of simulation exercises. Throughout the whole programme they would be guided by specially selected mentors from the educational and business communities, who would evaluate, counsel, direct and instruct as required. Participation of both races is essential, not only because they have to learn to work together in future, but because white attitudes also require considerable modification if they are to be effective in the new society that we hope will come about in Zimbabwe. The learning will not be confined to one party only. I believe that business would reap a handsome return from financing a plan of the kind I have described.

\section{Industrial relations}

There is one further matter to which I must briefly refer. It concerns industrial relations. I expect that labour relations will change considerably in the next decade. Until now the management/labour position was predominantly a white-black dichotomy, inevitably coloured by race attitudes. Gradually this racial element will disappear; economic and political considerations and interests will determine relationships and conflicts, though it would be too much to expect that history will not leave an aftermath. It is to be hoped that the policies to be adopted in this new era will not only succeed in keeping out such irrelevances, but will also steer development towards cooperative goals and avoid the labour-management confrontations that mar industrial relations in Europe. Zimbabwe has had its share of bitter political conflicts. It cannot afford any in the labour field in the years that lie ahead.

\section{Interface}

\section{Leadership for the 80's}

\author{
Grant Schutte
}

Acting Director, School of Business Leadership.

University of South Africa, P.O. Box 392, Pretoria 0001

From a speech at the MBL graduation dinner, Johannesburg.

9 May 1980

During 1979 and early 1980 a climate of change which has no precedent was created in the Republic of South
Africa. This climate was initiated by the Riekert and Wiehahn Reports, and the momentum of change was greatly increased by statements and actions of $\mathrm{Mr} \mathrm{P} \mathrm{W}$ Botha after his election as Prime Minister. His programmes dealing with the rationalization of Government, cooperation with the private sector, the development of a co-ordinated national strategy, and his envisaged Constellation of Southern African States, are only a few of the dramatic changes which have contributed to this climate in the Republic of South Africa.

At the same time, events in the international political and economic arenas such as the energy crisis, the weakness of the dollar and the increase in the gold price, have led to a strengthening of the South African economy. Furthermore, because of South Africa's mineral resources, especially gold, and its potential for relative independence with regard to liquid energy, the South African economy tends to become more favourable as the international economy becomes less favourable. This, together with the tax reforms and fiscal discipline introduced by Finance Minister Owen Horwood, has led to an economic optimism which has intensified the climate of change.

This climate of change has two consequences:

- Firstly, it has created expectations at both the national and international level.

- Secondly, and this is more important, it has created opportunities for both private and public sector leadership.

\section{Expectations}

As far as expectations are concerned, four groups can be distinguished.

Entrepreneurs expect a return to a higher degree of free enterprise in the economy. This means they expect less restrictive and protective legislation, less bureaucracy and thus more freedom in entrepreneurial decisionmaking. This in itself will bring about a greater challenge to leadership in the private sector during the 1980's. It will also set greater demands for leadership on the part of the public sector to satisfy the requirements of a freer economic environment, if the expectations of the entrepreneurs are to be met.

The black community expect change in both the socio/political and the economic arena. In the socio/ political arena the expectations which have been created relate to some sort of participation in the legislative decision-making process of the country, both at national and at regional levels. Satisfying these expectations will be a major challenge to the political and governmental leaders in the country.

Economic expectations have also been created in the black community. They expect more and more equal employment opportunities, better and in many cases equal wages, less discrimination - certainly less statutory discrimination - more mobility and at the same time more stability in employment. A better standard of living is expected by all urban and even rural black communities. If these expectations are to be satisfied, dynamic leadership at all levels in the political arena as well as the public and private sectors is required. 
The white community also has expectations. As a consumer it is looking for economic stability in the sense of maintaining its purchasing power. Increases in salaries are being compared with the inflation rate, and if improvement of the living standard is to be maintained, leadership in both the public and private sectors is required with a much greater emphasis on rewards in relation to productivity in both the public and private sectors. Effective fiscal and monetary leadership is also required. Whereas it seems as if the fiscal and monetary policy is being well managed, a tremendous responsibility rests on both the public and private sector leadership to create a productivity-related promotion and reward culture if the expectations of the white community for economic stability are to be met.

This community also expects political security. It is clear that, if not in total, a large part of the white community is becoming conditioned to the thought of sharing the political, economic and in a sense the social pies in South Africa. They do, however, expect to retain at least what they consider to be their fair share of these pies.

Political leadership is required to provide this assurance so that the white community can get on with the job of making a major contribution towards increasing the standard of living of the whole country.

The international community also harbours expectations. They have taken note of the many changes proposed by the Prime Minister, Mr P W Botha. They detect a new dispensation and they seem to like the modus vivendi. It is probably true to say that they hope the momentum of the change that has been initiated is maintained, and particularly that what is currently a statement of objectives will become a reality. They will be looking for participation by all groups concerned in political and geopolitical decision-making as well as an increase in the economic welfare of primarily the black community. If improvement in our international relationships is to be maintained, real political leadership will be required in the 1980's.

From the aforegoing it is clear that the 1980's are going to pose a great challenge to leadership in all areas and at all levels.

\section{Leadership}

A climate for change has been created. This is a fact. Expectations have developed. This is a fact.

Only bold leadership of the highest order can seek out the opportunities inherent in the climate for change, and bring about the change which will satisfy the expectations that have been created.

This leadership will have to be active and not passive. It has to be characterized by active change. Leaders will be required to be sensitive to, and to anticipate the expectations which have been created. They must seek opportunities to satisfy these expectations and initiate the change that is required to do so.

There will be no place for reactive leadership in the 1980 's - in fact, reactive leadership is probably the greatest threat to South Africa in this era.

Leadership in the 1980's will be risky and, therefore, leaders will only be successful if they are prepared to take risks. Many of the decisions will involve the emotions of people. Many measures will initially be unpopular and will not please everyone, but avoiding the risks inherent in taking these decisions could lead to increased tension and eventually to social and economic disruptions. The decisions will, however, have to be taken, the risks associated with them assessed, and these risks will have to be managed with courage and boldness. There is no place for risk avoidance in the leadership of the 1980's.

Leadership in the 1980's will have to be more innovative and less administrative. Traditional practices will have to be questioned as these practices catered for the 1970's. Existing constraints should be considered opportunities for change, and the change should be creative and innovative and aimed at satisfying the expectations of society in the broader sense. The change that is in troduced will, however, always have to be economically sound, as both the individual organization and the country as a whole have to be financially successful if they are to be socially responsible.

Leaders in the 1980's will have to address the strategic and important issues. They will simply have to make the time to do so. They will have to delegate the running of the organization to subordinates so that they can concentrate on the real decisions. This pre-supposes a streamlined and efficient management and administrative structure. They will have to take a broad approach, seek out the strategic and critical issues, interact with their peers in public and/or private sectors and create a new structure of 'things' that will be economically viable and socially acceptable.

Finally, leadership in the 1980's will of necessity have to be participative. It must be participative in the entrepreneurial sense, insofar as creativeness and innovation may be found on any level in every organization and no potential contributor or source of suggestions should be overlooked.

If the opportunities inherent in the climate for change are to be identified and the expectations of the employees on the one hand, and of society on the other, are to materialize, leadership cannot be exercised in isolation. This does not mean that decision-making is to be participative. On the contrary, the boldness required by the leadership of the 1980's is an individual boldness and an individual capacity to take risks and to address strategic issues.

In summary, leadership of the 1980's requires action leadership, the capacity to take risks and to manage these risks. It is an innovative leadership with the ability to identify and address strategic issues. It has to be participative in the entrepreneurial sense but individualistic in the decision-making sense. Above all, it has to be a bold leadership.

Finally, a word of warning. The expectations and the opportunities inherent in the climate for change also hold the germ of threat. These same opportunities can very easily turn into threats if the kind of leadership which is required for the 1980's does not materialize. These potential threats will flow from the expectations that have been created and can very easily result in political chaos and economic disaster. I believe that the 1980's are going to demand a quality of leadership never yet experienced in the history of South Africa. 